ISSN 2080-1653

DOI 10.24917/20801653.322.1

\author{
GRAŻYNA WĘGRZYN \\ Uniwersytet Ekonomiczny we Wrocławiu, Polska \\ Wrocław University of Economics, Poland
}

\title{
Innowacyjność gospodarek w kontekście zmian strukturalnych w zatrudnieniu i kształceniu
}

\section{Innovativeness of Economies in the Context of Structural Changes in Employment and Education}

\begin{abstract}
Streszczenie: Opracowanie ma na celu zidentyfikowanie cech struktury zatrudnienia i struktury kształcenia sprzyjających innowacyjności gospodarki. Założono, że innowacyjność gospodarki jest determinowana z jednej strony przez jej zmiany strukturalne, wyrażające się w nowoczesnej strukturze zatrudnienia, a z drugiej przez strukturę kształcenia na poziomie wyższym, odpowiadającą potrzebom innowacyjnej gospodarki. Opracowanie podzielono na trzy części. W pierwszej, na podstawie wartości wskaźnika Summary Innovation Index (SII), wybrano gospodarki Unii Europejskiej o najwyższym poziomie innowacyjności jako benchmark do dalszej analizy. W części drugiej dokonano analizy porównawczej struktury zatrudnienia poszczególnych gospodarek Unii Europejskiej. W części trzeciej analizie porównawczej poddano liczbę i strukturę absolwentów szkół wyższych według kierunków kształcenia. Zakres czasowy analizy obejmuje lata 2008-2016. Zakres przestrzenny obejmuje Unię Europejską (28 państw). W opracowaniu wykorzystano metody analizy opisowej i analitycznej, w tym porównawczej. Z przeprowadzonej analizy wynika, że kraje zaliczane do liderów innowacji wyznaczają kierunki zmian strukturalnych, w jakich mogą, ale nie muszą, podążać kraje je doganiające. Z kolei zmiany struktury gospodarki powodują modyfikację poziomu i kierunków kształcenia.
\end{abstract}

\footnotetext{
Abstract: The article attempts at identifing the structural characteristics of both employment and education that are conducive to innovativeness of national economies. The author assumes that innovation is determined on the one hand by structural changes in the economy, as manifested in a modern employment structure, and on the other by the structure of higher education which corresponds to the needs of innovative economy. This study report consists of three sections. In the first one, the Summary Innovation Index (SII) was used as the instrument for selecting the European economies with the highest level of innovation to establish the benchmark for further analysis. The second part presents results of a comparative study on the structure of employment across the EU member countries. The comparative analysis is continued in the third part, but there it focuses on the number and structure of higher education graduates by field of study. The analysis covers the years 2008-2016 and its spatial scope covers the EU-28. The methods used include both descriptive and analytical approach, including comparative analysis. The analysis results show that the countries normally seen as the "Leaders of Innovation" set certain directions of structural change which may or may not be followed by the runners-up. Changes in the structure of economy, in their turn, give rise to changes in the level and fields of education.
} 
Słowa kluczowe: innowacyjność; kierunki kształcenia; zatrudnienie; zmiany strukturalne

Keywords: innovation; employment; fields of education; structural changes

Otrzymano: 29 października 2017

Received: 29 October 2017

Zaakceptowano: 12 maja 2018

Accepted: 12 May 2018

\section{Sugerowana cytacja / Suggested citation:}

Węgrzyn, G. (2018). Innowacyjność gospodarek w kontekście zmian strukturalnych w zatrudnieniu i kształceniu. Prace Komisji Geografii Przemysłu Polskiego Towarzystwa Geograficznego, 32(2), 7-20. https://doi. org/10.24917/20801653.322.1

\section{WSTĘP}

Gospodarki, współcześnie określane jako gospodarki oparte na wiedzy (knowledge-based economy), znajdują się w nieustannej ewolucji, której następstwem jest rozwój gospodarczy i społeczny. Ewolucja to proces przechodzenia od form prostych i homogenicznych do form bardziej złożonych, heterogenicznych i lepiej dostosowanych, doskonalszych. Oznacza to, że struktura każdej gospodarki ewoluuje w kierunku rosnącej złożoności i hierarchiczności, czego przejawem są nierówności pod względem posiadania określonych dóbr i wartości lub dostępu do nich (Włodarczyk, 2011). Struktury gospodarek wykazują zmiany w udziałach poszczególnych części składowych w całości gospodarki, np. wartości dodanej czy zatrudnienia. Gospodarki charakteryzują się różnymi strukturami, które odzwierciedlają poziom rozwoju społeczno-gospodarczego, ale także wskazują na specyfikę gospodarki danego kraju. Czynnikiem odpowiedzialnym za zmiany strukturalne jest postęp techniczny, stanowiący wynik nauki i wiedzy (Zimmermann, 2002).

Gospodarki charakteryzują się coraz większym wykorzystywaniem wiedzy, prowadzącym do zwiększania innowacyjności. Innowacyjność jest powiązana ze zdolnością do generowania i wykorzystywania wiedzy, kreatywnością oraz przedsiębiorczością (Potencjał innowacyjny gospodarki..., 2016). Aktualnie za główną siłę napędową gospodarek uznaje się wiedzę i innowacje. Innowacje, będąc efektem komercyjnego wykorzystania wiedzy, decydują o pozycji konkurencyjnej przedsiębiorstw, regionów i gospodarek. Wiedza, rozumiana jako zdolność do działania, przekłada się na innowacje i odgrywa decydującą rolę w stymulowaniu rozwoju gospodarczego i społecznego każdego kraju oraz regionu (Matusiak, 2005). Pojęciem ściśle związanym z gospodarkami opartymi na wiedzy jest innowacyjność, czyli zdolność do tworzenia, wykorzystywania i dystrybuowania osiągnięć wiedzy. Za jedną z głównych determinant innowacyjności uznaje się zasoby pracy, zwłaszcza wysoko wykwalifikowane kadry. Osoby z wyższym wykształceniem, które dysponują odpowiednim zasobem wiedzy, umiejętności i kompetencji społecznych, są potencjałem dla wzrostu innowacyjności. Wiedza stanowi zakumulowany zasób informacji, możliwy do wykorzystania i zastosowania (Howells, 2002). Oznacza to, że szkoły wyższe odgrywają ogromną rolę w stymulowaniu innowacji, bo z jednej strony dostarczają gospodarce wysoko wykwalifikowanych, kreatywnych pracowników, a z drugiej same są producentami wiedzy. Zarówno tej, która jest łatwo aplikowana (badania stosowane), jak i wiedzy będącej w sferze teorii (badania podstawowe) (Colyvas i in., 2002). 
Opracowanie ma na celu zidentyfikowanie wyróżników (cech szczególnych) struktury zatrudnienia i struktury kształcenia na poziomie wyższym sprzyjających innowacyjności gospodarki. Zakłada się, że innowacyjność gospodarki jest determinowana z jednej strony przez jej zmiany strukturalne, wyrażające się w nowoczesnej strukturze zatrudnienia, a z drugiej przez strukturę kształcenia na poziomie wyższym, odpowiadającą potrzebom innowacyjnej gospodarki.

Opracowanie składa się z trzech części. W pierwszej, na podstawie wartości wskaźnika Summary Innovation Index (SII), wybrano gospodarki Unii Europejskiej o najwyższym poziomie innowacyjności jako benchmark do dalszej analizy pod względem struktury zatrudnienia i kierunków kształcenia. W części drugiej dokonano analizy porównawczej struktury zatrudnienia w poszczególnych gospodarkach. Stopień podobieństwa struktur gospodarek przedstawiono za pomocą udziału pracujących w sekcjach PKD w ogólnej liczbie pracujących. Zidentyfikowano cechy charakterystyczne dla gospodarek będących liderami innowacyjności. W części trzeciej analizie porównawczej poddano liczbę i strukturę absolwentów szkół wyższych w poszczególnych krajach Unii Europejskiej, ze szczególnym uwzględnieniem struktury absolwentów w krajach referencyjnych. Zakres czasowy analizy obejmuje lata 2008-2016. Zakres przestrzenny podjętych w pracy rozważań obejmuje obszar Unii Europejskiej, czyli 28 państw, ze szczególnym uwzględnieniem Polski. W opracowaniu wykorzystano metody analizy opisowej i analitycznej, w tym porównawczej.

\section{INNOWACYJNOŚĆ GOSPODAREK - LIDERZY INNOWACYJNOŚCI}

Ekonomiści są w większości zgodni, że innowacje, szczególnie innowacje technologiczne, są najważniejszym źródłem wzrostu gospodarczego (Kasperkiewicz, 2014). Decydują o nowoczesności, jak i o konkurencyjności gospodarek. Szeroko rozumiana problematyka innowacji i innowacyjności jest jednak stosunkowo nowym przedmiotem zainteresowań naukowych. Innowacyjność najogólniej oznacza potencjał do tworzenia szeroko rozumianych innowacji. Wiąże się z aktywnym zaangażowaniem w procesy innowacyjne oraz podejmowaniem działań w tym kierunku (Nowakowska, 2009). Warunkowana jest przez posiadane zasoby (rzeczowe, ludzkie, finansowe) oraz umiejętności uczestnictwa w procesach tworzenia, wdrażania i absorpcji. Według P. Niedzielskiego innowacyjność jest cechą podmiotów gospodarczych lub gospodarek polegającą na zdolności do tworzenia i wdrażania innowacji oraz do ich absorpcji i wykorzystania (Niedzielski, 2005). Podkreśla się, że innowacyjność ściśle wiąże się z posiadanymi zasobami, ale także z umiejętnością ich wykorzystywania. Innowacyjność, rozumiana jako zdolność do kreowania i wdrażania innowacji, stanowi obecnie jeden z kluczowych czynników determinujących rozwój gospodarczy i trwałą konkurencyjność gospodarek (Wysokińska, 2011). Zwiększanie możliwości absorpcyjnych nowych technologii i innowacji przyczynia się do rozwoju poszczególnych sektorów gospodarki i daje możliwość wzrostu wartości całej gospodarki (Gajda, 2015).

Jednym ze źródeł informacji o poziomie innowacyjności gospodarek jest raport Europejska tablica wyników innowacji w 2017 r. (European Innovation Scoreboard, EIS) (European Innovation Scoreboard, 2017). Prezentowany w nim złożony wskaźnik Summary Innovation Index (SII) służy do syntetycznej oceny poziomu innowacyjności krajów Unii Europejskiej (Nowak, 2012). Miary innowacyjności zawarte w EIS ulegają ciągłej ewolucji, wzrasta liczba czynników, które decydują o poziomie innowacyjności 
kraju. W raporcie Europejska tablica wyników innowacji w 2017 r. zmieniono ramy oceny w stosunku do edycji z lat poprzednich. Pozwoliło to na lepsze dostosowanie wymiarów europejskiej tablicy wyników innowacji do zmieniających się priorytetów politycznych, poprawę jakości wskaźników, lepsze odzwierciedlenie nowych, wyłaniających się zjawisk, np. digitalizacji. Ostatecznie w EIS 2017 do oceny poziomu innowacyjności wykorzystano 27 wskaźników szczegółowych podzielonych na cztery główne kategorie i dziesięć tzw. wymiarów innowacji (tab. 1). Po raz pierwszy wprowadzono wymiar dotyczący środowiska sprzyjającego innowacjom.

Tab. 1. Europejska tablica wyników innowacji w 2017 roku - grupy wskaźników i wymiary innowacji

\begin{tabular}{|l|l|}
\hline Rodzaje wskaźników & Wymiary innowacji \\
\hline warunki ramowe & $\begin{array}{l}\text { zasoby ludzkie } \\
\text { atrakcyjne systemy badań } \\
\text { środowisko sprzyjające innowacjom }\end{array}$ \\
\hline inwestycje & $\begin{array}{l}\text { finansowanie i wsparcie } \\
\text { inwestycje przedsiębiorstw }\end{array}$ \\
\hline działania innowacyjne & $\begin{array}{l}\text { innowatorzy } \\
\text { powiązania } \\
\text { aktywa intelektualne }\end{array}$ \\
\hline wpływ & $\begin{array}{l}\text { wpływ na poziom zatrudnienia } \\
\text { wpływ na wielkość sprzedaży }\end{array}$ \\
\hline
\end{tabular}

Źródło: opracowanie własne

W 2016 roku w Unii Europejskiej złożony wskaźnik innowacyjności SII wyniósł 0,503 ${ }^{1}$ (European Innovation Scoreboard, 2017). Najwyższą wartość wskaźnika uzyskała Szwecja $(0,708)$, a najniższą Rumunia $(0,167)$. W europejskiej tablicy wyników innowacji państwa członkowskie podzielono - w oparciu o wynik sumarycznego wskaźnika innowacyjności SII - na cztery różne grupy: liderzy innowacji, państwa doganiające liderów, umiarkowani innowatorzy oraz innowatorzy o skromnych wynikach (tab. 2).

Tab. 2. Kraje Unii Europejskiej według poziomu innowacyjności SII w 2016 roku

\begin{tabular}{|l|l|}
\hline Grupy państw & Wskaźnik Summary Innovation Index (SII) \\
\hline liderzy innowacji & $\begin{array}{l}\text { Szwecja }(0,708), \text { Dania }(0,675), \text { Finlandia }(0,646), \text { Holandia } \\
(0,639), \text { Wielka Brytania }(0,618), \text { Niemcy }(0,609)\end{array}$ \\
\hline doganiający liderów & $\begin{array}{l}\text { Irlandia }(0,609), \text { Belgia }(0,602), \text { Luksemburg }(0,598), \text { Austria } \\
(0,591), \text { Francja }(0,568), \text { Słowenia }(0,485)\end{array}$ \\
\hline umiarkowani innowatorzy & $\begin{array}{l}\text { Czechy }(0,416), \text { Portugalia }(0,409), \text { Estonia }(0,393), \text { Litwa }(0,391), \\
\text { Hiszpania }(0,386), \text { Malta }(0,373), \text { Włochy }(0,371), \text { Cypr }(0,369), \\
\text { Słowacja }(0,345), \text { Grecja }(0,337), \text { Węgry }(0,332), \text { Łotwa }(0,287), \\
\text { Chorwacja }(0,270), \text { Polska }(0,270)\end{array}$ \\
\hline słabi innowatorzy & Bułgaria $(0,234)$, Rumunia $(0,167)$ \\
\hline
\end{tabular}

Źródło: opracowanie własne na podstawie: European Innovation Scoreboard (2017)

W grupie państw zaliczanych do liderów innowacji znalazło się sześć państw, czyli Szwecja, Dania, Finlandia, Holandia, Wielka Brytania (po raz pierwszy w tej grupie)

\footnotetext{
${ }^{1}$ Wskaźnik SII przyjmuje wartości od 0 do 1 . Im wyższa wartość wskaźnika, tym wyższy poziom innowacyjności.
} 
i Niemcy. Są to państwa, których wyniki w zakresie innowacji są zdecydowanie powyżej średniej UE (28) i które posiadają zrównoważony system badań i innowacji, tzn. osiągają najlepsze wyniki we wszystkich obszarach innowacyjności: od warunków ramowych sprzyjających innowacjom, przez publiczne i prywatne inwestycje w badania naukowe i innowacje, działania innowacyjne przedsiębiorstw, do efektów działań innowacyjnych przedsiębiorstw w zakresie zatrudnienia i wielkości sprzedaży. Państwa należące do grupy liderów innowacji w dalszej części opracowania będą stanowiły benchmark, czyli punkt odniesienia dla porównań w zakresie struktury zatrudnienia i kształcenia².

W grupie doganiających liderów znalazło się sześć państw, czyli Irlandia, Belgia, Luksemburg, Austria, Francja i Słowenia. Są to państwa, które uzyskały wyniki w zakresie innowacji na poziomie powyżej lub blisko średniej UE. Polska znalazła się w grupie umiarkowanych innowatorów wraz z trzynastoma innymi państwami, osiągającymi wyniki w zakresie innowacji poniżej średniej UE. Bułgaria i Rumunia z wynikami zdecydowanie poniżej średniej UE znalazły się w grupie słabych innowatorów.

\section{STRUKTURA GOSPODARKI I JEJ EWOLUCJA}

Przyjmuje się, że struktura gospodarki to pewnego rodzaju obraz jej podziału na główne elementy odzwierciedlające stan gospodarki oraz trendy podziału pracy. Gospodarki, znajdując się na różnym poziomie rozwoju gospodarczego, charakteryzują się odmiennymi strukturami. Wynika to z tego, że każda gospodarka jest złożonym systemem społeczno-ekonomicznym, który podlega ciągłym zmianom. Struktura gospodarki to inaczej relacje między poszczególnymi elementami gospodarki a jej całością (Jakóbik, 2000). Zmiany zachodzące w strukturze gospodarki najczęściej następują według określonych wzorców, w zależności od jej etapu i charakteru rozwoju (Zaidi, Mukhopadhyay, 2006). Można je rozpatrywać na wielu płaszczyznach. Najczęściej z punktu widzenia udziału poszczególnych sektorów w tworzeniu wartości dodanej brutto albo w ogólnej liczbie pracujących.

Zmiany strukturalne najczęściej są efektem zmian technologicznych w produkcji, następują na skutek innowacji redukujących koszty produkcji, ale także wprowadzających nowe produkty czy usługi. W konsekwencji wpływa to na poziom produkcji i sektorowy skład gospodarki (Salvadori, Commendatore, Tamberi, 2009). L. Pasinetti utrzymuje, że ekspansja nowoczesnych sektorów gospodarki nie jest jednolita, gdyż tempo wzrostu wydajności pracy jest różne. W konsekwencji mamy do czynienia z różną dynamiką zmian strukturalnych w zatrudnieniu (Pasinetti, 2006).

Współczesne gospodarki charakteryzują się zmianami wynikającymi z ich przechodzenia w kierunku gospodarek opartych na wiedzy. Wiedza jest kluczowym atutem w uzyskiwaniu przewagi konkurencyjnej zarówno przedsiębiorstw, jak i gospodarek. Przechodzenie gospodarek i cywilizacji z fazy industrialnej do kognitywnej charakteryzuje się tym, że głównym źródłem nowo tworzonej wartości stają się innowacje oraz wytwarzanie wiedzy i jej stosowanie (Kuciński, 2010). Obecnie we wszystkich sektorach gospodarki widać proces nasycania wiedzą, która inicjuje innowacje. Następuje modernizacja piramidy dobrobytu, w której główną rolę odgrywa wiedza (Thurow,

${ }^{2}$ Pojęcie „benchmark” ma swoje korzenie w geodezji, gdzie oznaczało punkt odniesienia przy wyznaczaniu lokalizacji lub wysokości obiektu nad poziomem morza. 
Ryc. 1. Dynamika liczby pracujących w Unii Europejskiej (28) według sektorów w latach 2008-2016 (w \%)

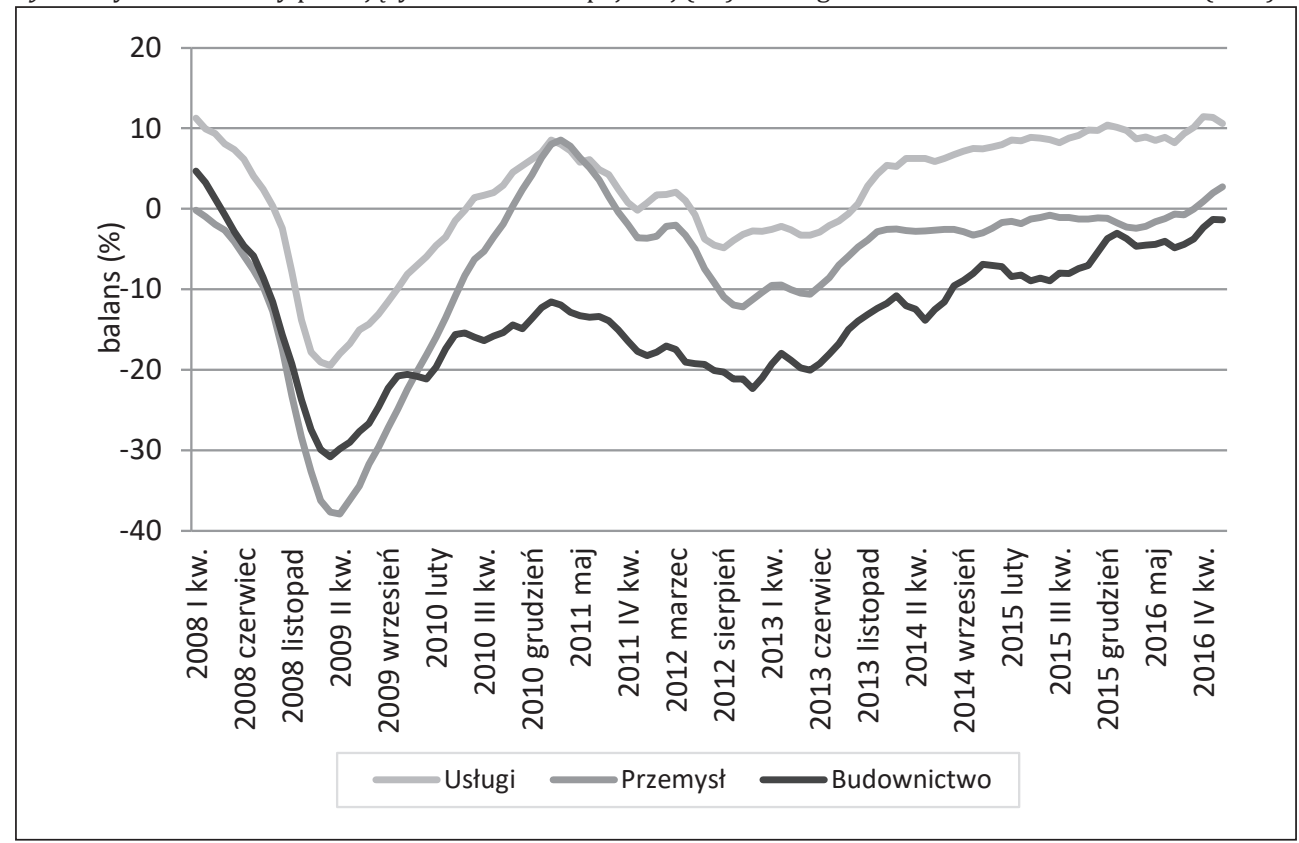

Źródło: Employment and Social Developments in Europe. Quarterly Review (2017: 15)

2006). Co więcej, zachodzące zmiany w strukturze gospodarki stają się wyznacznikiem postępu ekonomicznego, społecznego i kulturalnego.

W latach 2008-2016 w Unii Europejskiej (28 państw), po znacznym spadku zatrudnienia w 2009 roku na skutek światowego kryzysu, największy przyrost miejsc pracy wystąpił w sektorze usług (ryc. 1). Dynamika wzrostu zatrudnienia w IV kwartale 2016 roku wyniosła w usługach 10,4\%, a w przemyśle 2,7\%. W budownictwie od II kwartału 2008 roku dynamika zatrudnienia była ujemna.

Zmiany zachodzące w liczbie pracujących prowadzą do zmian w strukturze zatrudnienia. Struktura zatrudnienia z jednej strony jest wyrazem zmian zachodzących w gospodarce pod wpływem nowych technologii lub zmian w strukturze popytu globalnego, a z drugiej jest zasobem określającym zdolność gospodarek do zmian. Stanowi swego rodzaju potencjał niezbędny do kreowania nowej gospodarki, gospodarki opartej na wiedzy, do rozwoju tych dziedzin, które odpowiadają za tworzenie, rozpowszechnianie i wykorzystywanie wiedzy (Węgrzyn, 2015).

W latach 2008-2016 w Unii Europejskiej (28) nastąpiły zmiany strukturalne w zatrudnieniu we wszystkich sektorach gospodarki. Udział zatrudnionych w sektorze usług zwiększył się o 3 p.p. do 73,1\% ogółu zatrudnionych, zmniejszył się w sektorze rolniczym (o 0,4 p.p. do 5\%) i w przemyśle (o 2,6 p.p. do 21,9\%). Podstawowymi elementami struktury gospodarczej kraju, charakteryzującymi działowo-gałęziową strukturę gospodarki, są sekcje PKD. Trzy sekcje, czyli przetwórstwo przemysłowe (sekcja C), budownictwo (sekcja F) i rolnictwo (sekcja A), odpowiadały za 96\% utraconych miejsc pracy w latach 2008-2016 (ryc. 2). Wzrost zatrudnienia nastąpił w sekcjach usługowych, w szczególności w sekcjach opartych na wysoko zaawansowanej wiedzy. Największy wzrost dotyczył działalności naukowej (sekcje M-N), 
Ryc. 2. Zmiany w zatrudnieniu w Unii Europejskiej (28) w latach 2008-2016 (w mln, w \%)

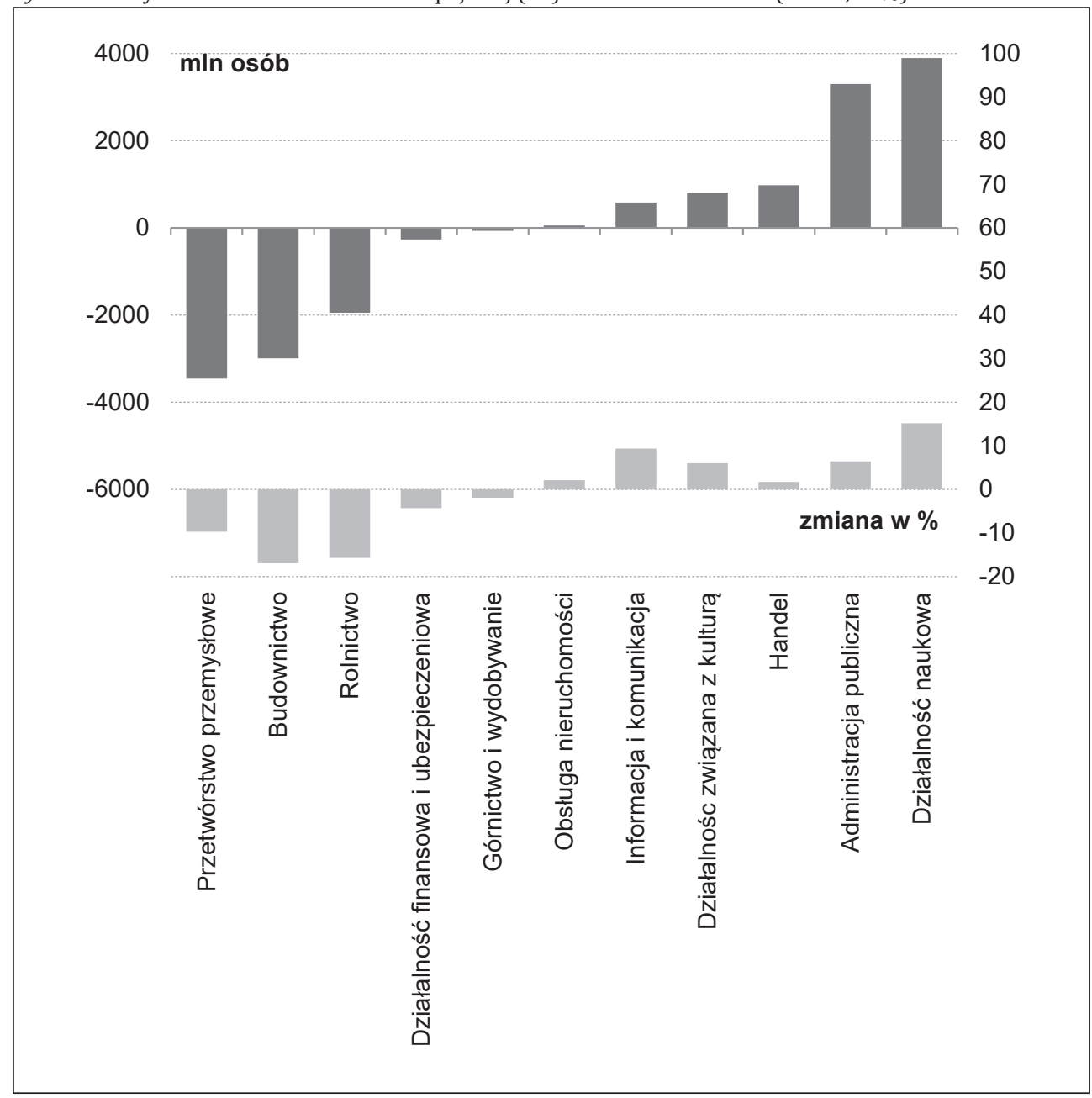

\section{Objaśnienia:}

Sekcje PKD. (A) Rolnictwo, leśnictwo, łowiectwo i rybactwo; (B-E) B - Górnictwo i wydobywanie, D - Wytwarzanie i zaopatrywanie w energię elektryczną, gaz, parę wodną, gorącą wodę i powietrze do układów klimatyzacyjnych, E - Dostawa wody; gospodarowanie ściekami i odpadami oraz działalność związana z rekultywacją; (C) Przetwórstwo przemysłowe; (F) Budownictwo; (G-I) G - Handel hurtowy i detaliczny; naprawa pojazdów samochodowych, włączając motocykle, H - Transport i gospodarka magazynowa, I - Działalność związana z zakwaterowaniem i usługami gastronomicznymi; (J) Informacja i komunikacja; (K) - Działalność finansowa i ubezpieczeniowa; (L) Działalność związana z obsługą rynku nieruchomości; (M-N) M- Działalność profesjonalna, naukowa i techniczna, N - Działalność w zakresie usług administrowania i działalność wspierająca; (O-Q) 0 - Administracja publiczna i obrona narodowa; obowiązkowe zabezpieczenia społeczne, P - Edukacja, Q - Opieka zdrowotna i pomoc społeczna; (R-U) R - Działalność związana z kulturą, rozrywką i rekreacją, S - Pozostała działalność usługowa, T - Gospodarstwa domowe zatrudniające pracowników; gospodarstwa domowe produkujące wyroby i świadczące usługi na własne potrzeby, U - Organizacje i zespoły eksterytorialne.

Źródło: Eurostat (2018) 
obsługi nieruchomości (sekcja L), informacji i komunikacji (sekcja J) oraz administracji publicznej (sekcje O-Q).

W poszczególnych gospodarkach Unii Europejskiej zmiany strukturalne zachodzą w różnym tempie i wykazują zarówno upodabnianie się struktur, jak i narastanie różnic. W badanym okresie zwiększył się udział zatrudnionych w sekcjach: Działalność profesjonalna, naukowa i techniczna (M), Działalność w zakresie usług administrowania i działalność wspierająca (N) oraz w sekcji Informacja i komunikacja (J) w ogólnej liczbie zatrudnionych. Największy wzrost udziału zatrudnionych w sekcjach $\mathrm{M}-\mathrm{N}$ zanotowały: Rumunia (5,3 p.p.), Malta (5,2 p.p.), Cypr (3,3 p.p.), Łotwa (2,3 p.p.), Irlandia (2,3 p.p.) i Polska (2,2 p.p.). W sekcji J najwięcej nowych miejsc pracy powstało w Rumunii (2,9 p.p.), Bułgarii (2,7 p.p.) i na Łotwie (2,1 p.p.). Powyższe zmiany świadczą o postępującej tzw. konwergencji warunkowej, która przebiega w poszczególnych państwach w różnym tempie. Konwergencja warunkowa oznacza, że państwa mogą różnić się od siebie zarówno pod względem ogólnych charakterystyk (czyli zasobu kapitału fizycznego i ludzkiego, wskaźników demograficznych, egzogenicznego postępu technicznego), jak i z powodu różnych czynników endogenicznych (np. innowacyjności, struktury gospodarczej, systemu finansowego, polityki gospodarczej) (Zielińska-Głębocka, 2012).

Struktura zatrudnienia w poszczególnych państwach Unii Europejskiej jest bardzo zróżnicowana. W krajach przyjętych jako benchmark pod względem innowacyjności, czyli zaliczanych do liderów innowacji, udział zatrudnionych w usługach wahał się w 2016 roku od 68,9\% (Niemcy) do 81,7\% (Holandia), w przemyśle od 17,5\% (Holandia) do 30,6\% (Niemcy) oraz w rolnictwie od 0,5\% (Niemcy) do 1,2\% (Finlandia). Kraje te posiadają rozwinięty sektor usług, jednak z uwagi na jego heterogeniczność należy rozpatrywać odrębnie poszczególne rodzaje działalności. Duże różnice pomiędzy UE (28) a liderami innowacji występują w wielkości udziału zatrudnionych w sekcjach O-Q - Administracja publiczna i obrona narodowa; Obowiązkowe zabezpieczenia społeczne; Edukacja; Opieka zdrowotna i pomoc społeczna; oraz M-N - Działalność

Ryc. 3. Udział zatrudnionych w wybranych sekcjach PKD w 2016 roku (w \% ogółu zatrudnionych)

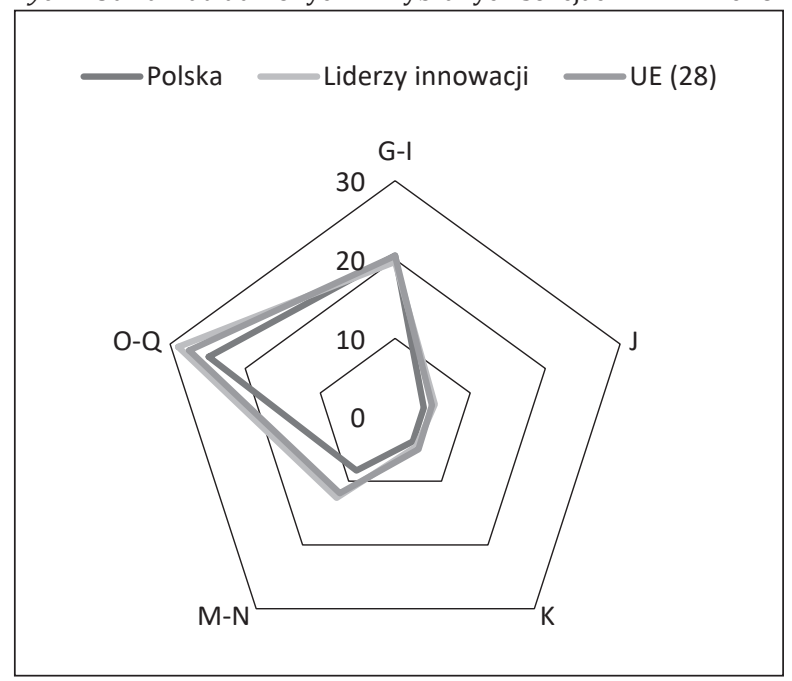

Źródło: opracowanie własne 
profesjonalna, naukowa i techniczna oraz Działalność w zakresie usług administrowania i działalność wspierająca, gdzie średnia dla UE (28) jest niższa niż średnia dla liderów innowacji (ryc. 3). Z kolei udział zatrudnionych w sekcjach G-I - Handel hurtowy i detaliczny oraz Transport i gospodarka magazynowa w UE (28) jest wyższy niż w krajach będących liderami innowacji.

Analiza struktury zatrudnienia według sekcji PKD wskazuje, że kraje będące liderami we wdrażaniu innowacji różnią się między sobą pod względem struktury zatrudnienia w usługach. Największa różnica pomiędzy najwyższym i najniższym odsetkiem zatrudnionych $\mathrm{w}$ danej sekcji w ogólnej liczbie zatrudnionych występuje w sekcjach $\mathrm{M}-\mathrm{N}$ i O-Q (ponad 6 p.p.). W związku z tak dużymi różnicami kraje zaliczane do liderów innowacji należy podzielić na trzy rodzaje. Pierwszy z nich to gospodarki oparte na działalności administracyjnej (sekcje O-Q), obejmującej trzy sekcje PKD, czyli działalność z zakresu administracji publicznej i obrony narodowej (sekcja 0), edukację (sekcja P) oraz opiekę zdrowotną (sekcja Q). Są to sekcje, których działalność w znacznej części jest finansowana z budżetu państwa. Udział zatrudnionych w sekcjach O-Q przekracza w Danii, Szwecji i Finlandii 30\% ogółu zatrudnionych. Drugi rodzaj stanowią gospodarki oparte na sektorze bankowym, gdzie zatrudnieni w sekcji K - Działalność finansowa i ubezpieczeniowa, stanowią ponad 7\% ogółu zatrudnionych. Typową gospodarką opartą na działalności finansowej jest Wielka Brytania, gdzie zatrudnieni w sekcji K w 2016 roku stanowili 7,1\% ogółu zatrudnionych. Trzeci rodzaj to gospodarki oparte na działalności naukowej (sekcje M-N), obejmującej dwie sekcje PKD, czyli M - Działalność profesjonalna, naukowa i techniczna oraz N - Działalność w zakresie usług administrowania i działalność wspierająca. Typowym przykładem takiej gospodarki jest Holandia, gdzie zatrudnieni w sekcjach M-N stanowili 17,5\% ogółu zatrudnionych. Struktura zatrudnienia w sektorze usług w gospodarce Niemiec nie wykazuje żadnych cech szczególnych,ani też podobieństwa do któregoś z wyróżnionych trzech rodzajów gospodarek. Charakteryzuje się jednak najwyższym udziałem zatrudnionych w przemyśle $(30,6 \%$ ogółu zatrudnionych).

Struktura zatrudnienia w Polsce różni się znacznie od struktury zatrudnienia w krajach będących liderami innowacji. Wyraźnie udział zatrudnionych w sekcjach $\mathrm{O}-\mathrm{Q}, \mathrm{K}$ oraz M-N jest niższy niż w grupie liderów innowacji.

\section{ABSOLWENCI SZKÓ£ WYŻSZYCH - ZMIANY ILOŚCIOWE I KIERUNKOWE}

W społeczeństwie opartym na wiedzy coraz więcej miejsc pracy wymaga relatywnie wysokiego poziomu wykształcenia, kwalifikacji oraz specjalistycznych umiejętności. Następuje proces przesuwania się od zawodów o niskim poziomie kwalifikacji do zawodów wymagających wyższych i najwyższych kwalifikacji (Edukacja dla pracy, 2007). Potrzeba wzrostu kwalifikacji została dostrzeżona w Strategii Europa 2020. Wyznaczono w niej cel, zgodnie z którym do roku 2020 co najmniej $40 \%$ osób w wieku 30-34 lat powinno posiadać wykształcenie wyższe. Nie ma wątpliwości, że szkoły wyższe odgrywają ważną rolę w życiu gospodarczym i społecznym. Są przede wszystkim instytucjami odpowiadającymi za kształtowanie kapitału ludzkiego i wytwarzanie wiedzy. W wielu regionach są one również znaczącymi pracodawcami i tym samym wnoszą istotny wkład w rozwój gospodarczy. Klasyczną sferą oddziaływania szkół wyższych jest kształtowanie kapitału ludzkiego (Goldstain, 2009). Zapewniając podaż wykwalifikowanych pracowników o danym profilu, uczelnia wyższa przyczynia się do 
Ryc. 4. Udział osób z wyższym wykształceniem w krajach Unii Europejskiej w roku 2008 i 2016 (w \% ogółu ludności w wieku 30-34 lata)

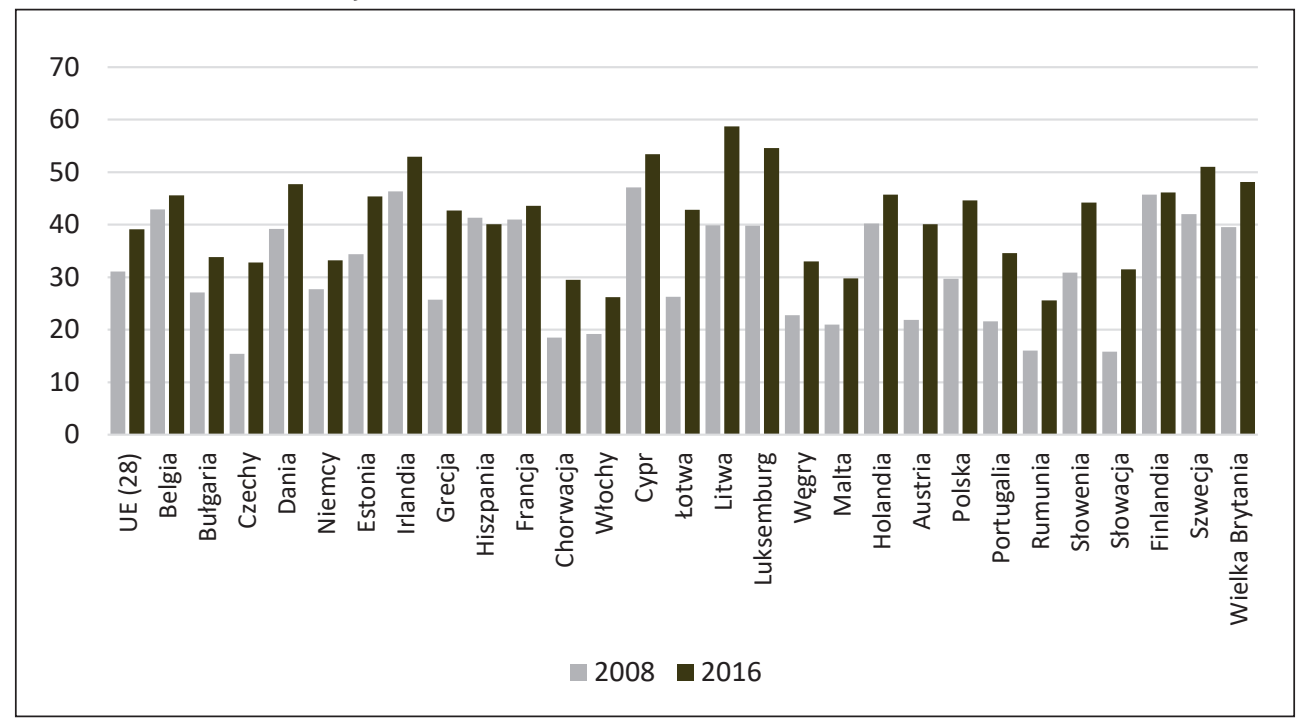

Źródło: opracowanie własne na podstawie danych Eurostatu (2018)

modernizacji struktury ekonomicznej miasta, regionu czy kraju. Oddziaływania tego nie można jednak ograniczać wyłącznie do jakości kapitału ludzkiego, pamiętając, że stanowi on o możliwościach absorpcyjnych firm w zakresie innowacyjności (Broström, Lööf, 2006). Aktualnie uczelnie stanowią również ważny element krajowych i regionalnych systemów innowacji.

Zgodnie z Międzynarodową Standardową Klasyfikacją Edukacji (International Standard Classification of Education, ISCED 1997)³, kształcenie na poziomie wyższym obejmuje dwa poziomy, czyli poziom 5 - Pierwszy etap kształcenia wyższego (który nie prowadzi bezpośrednio do zaawansowanych kwalifikacji badawczych) i poziom 6 - Drugi etap kształcenia wyższego (który prowadzi do zaawansowanych kwalifikacji badawczych). Znowelizowana Międzynarodowa Standardowa Klasyfikacja Kształcenia ISCED 2011 uwzględniła zmiany, jakie nastąpiły w systemach edukacji na całym świecie od ostatniej rewizji ISCED w 1997 roku. Zgodnie z ISCED 2011, kształcenie na poziomie wyższym (ISCED 5-8) obejmuje edukację na poziomie uniwersyteckim, studia podyplomowe i doktoranckie. Od 2008 roku w Unii Europejskiej (28) udział osób w wieku 30-34 lata z wyższym wykształceniem wzrósł z 31,1\% do 39,1\% w 2016 roku (Eurostat regional yearbook 2017, 2017). Największy wzrost wśród państw Unii Europejskiej zanotowały: Litwa (18,8 p.p.), Austria (18,2 p.p.), Czechy (17,4 p.p.) i Grecja (17,0 p.p.). Spadek wystąpił jedynie w Hiszpanii (1,2 p.p.). W 2016 roku 15 państw UE, w tym w Polska, spełniało już wyznaczony przez Strategię Europa 2020 cel (ryc. 4), tzn. 40\% osób w wieku 30-34 lat posiadało wykształcenie wyższe. Na Litwie odsetek ten wynosił 58,7\% osób w wieku 30-34 lat, co było najwyższym wskaźnikiem wśród państw Unii Europejskiej. Najniższy wskaźnik wystąpił w Rumunii (25,6\%). W 2008

${ }^{3}$ Do roku 2013 dane na temat poziomu edukacji i wykształcenia były klasyfikowane według ISCED 1997, a od roku 2014 robi się to według ISCED 2011. 
Ryc. 5. Udział absolwentów szkół wyższych w wybranych grupach kierunków kształcenia w 2016 roku (w \% ogółu absolwentów)

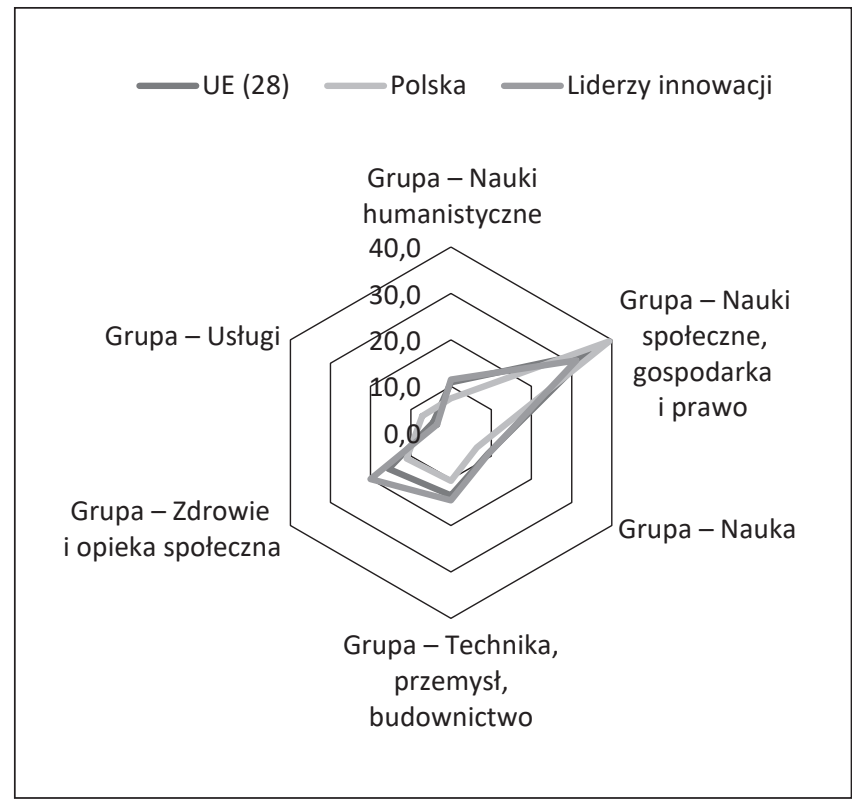

Źródło: opracowanie własne

roku różnica między najwyższym a najniższym odsetkiem osób z wyższym wykształceniem w ogólnej liczbie ludności w wieku 30-34 lat wynosiła 31,7\%, a w 2016 wzrosła do 33,1\%. W Polsce udział osób z wyższym wykształceniem zwiększył się z 29,7\% do 44,6\% w 2016 roku, czyli o 14,9 p.p. Od 2014 roku Polska spełnia kryterium Strategii Europa 2020 w tym zakresie.

Z przeprowadzonej analizy wynika, że w badanym okresie dokonały się korzystne zmiany ilościowe, którym towarzyszyły zmiany w strukturze kierunkowej kształcenia na poziomie wyższym. Struktura kształcenia na poziomie wyższym ma swoje źródła przede wszystkim w polityce edukacyjnej państwa (zwłaszcza w sposobie finansowania studiów), ale wynika także z poziomu kształcenia, szczególnie w zakresie przedmiotów ścisłych na niższych szczeblach edukacji. Oferta edukacyjna uczelni w poszczególnych krajach jest wypadkową polityki edukacyjnej kraju, zasobów kapitałowych, rozwoju badań (głównie w szkołach publicznych) oraz preferencji kandydatów. Analiza absolwentów szkół wyższych według kierunków kształcenia w poszczególnych krajach Unii Europejskiej wykazała, że w krajach będących liderami innowacyjności największy odsetek absolwentów szkół wyższych stanowili absolwenci kierunków: zdrowie i opieka społeczna oraz technika, przemysł i budownictwo (ryc. 5). Są to kierunki kształcenia wymagające wysokich nakładów finansowych.

Struktura kierunkowa kształcenia w Polsce wyraźnie odbiega od „wzorcowej”, czyli średniej dla liderów innowacji. Odsetek absolwentów szkół wyższych kierunków: usługi i nauki społeczne, gospodarka i prawo przewyższa średnią dla liderów innowacji i UE (28). Z kolei odsetek absolwentów kierunków: zdrowie i opieka społeczna oraz technika, przemysł, budownictwo jest zdecydowanie niższy niż w grupie liderów innowacji czy średniej dla UE (28). 


\section{ZAKOŃCZENIE}

Innowacyjność jest czynnikiem determinującym zmiany strukturalne zachodzące we współczesnych gospodarkach, czyli gospodarkach opartych na wiedzy. Kraje zaliczane do liderów innowacji wyznaczają kierunki zmian strukturalnych, w jakich mogą, ale nie muszą, podążać kraje je doganiające. Obserwuje się wzrost znaczenia sekcji usługowych - o dużym udziale kapitału opartego na wiedzy - odpowiadających za tworzenie, dystrybuowanie i wykorzystywanie wiedzy. Liderzy innowacji posiadają bardzo różne struktury zatrudnienia w usługach, co wymusiło podział na trzy rodzaje gospodarek. Pierwszy to gospodarki oparte na administracji publicznej, chrakteryzujące się silnym wzrostem udziału zatrudnienia w sekcjach związanych z działalnością ustawodawczą i wykonawczą, prowadzoną przez centralne organy administracji państwowej i samorządowej, z edukacją oraz z opieką zdrowotną (w sekcjach 0-Q). Najwyższym udziałem zatrudnionych w sekcjach O-Q w ogólnej liczbie zatrudnionych charakteryzowały się Dania, Szwecja i Finlandia (ponad 30\%). Drugi rodzaj to gospodarki oparte na działalności finansowej (Wielka Brytania), gdzie udział zatrudnionych w działalności finansowej i ubezpieczeniowej (sekcja K) przekracza 7\% ogółu zatrudnionych. Trzeci rodzaj to gospodarki oparte na działalności naukowej (Holandia), gdzie zatrudnienie w sekcjach M-N przekracza 17\% ogółu zatrudnionych. W Polsce udział zatrudnionych w sekcjach ważnych z punktu widzenia innowacyjności pozostaje na poziomie dużo niższym nie tylko niż poziom osiągany przez liderów innowacji, ale także niż średnia UE (28 państw). Polska sukcesywnie, ale jednak zbyt wolno, zmniejsza dystans rozwojowy w zakresie zmian strukturalnych.

Zmiany struktury gospodarki powodują modyfikację poziomu i kierunków kształcenia. We wszystkich państwach Unii Europejskiej w badanym okresie nastąpiły korzystne zmiany ilościowe, które przejawiają się w upowszechnianiu szkolnictwa wyższego. Dla wzrostu poziomu innowacyjności ważna jest odpowiednia podaż kapitału ludzkiego, dostosowanego nie tylko pod względem ilościowym, ale również pod względem struktury kierunkowej kształcenia. W krajach zaliczanych do liderów innowacji wśród absolwentów szkół wyższych wyraźnie przeważają absolwenci dwóch kierunków: zdrowie i opieka społeczna oraz technika, przemysł, budownictwo. Natomiast w krajach o niskim poziomie innowacyjności, w tym również w Polsce, wśród absolwentów szkół wyższych dominują absolwenci kierunków: usługi i nauki społeczne, gospodarka i prawo. Taka struktura kierunków kształcenia nie sprzyja wzrostowi poziomu innowacyjności gospodarki.

\section{Literatura \\ References}

Broström, A., Lööf, H. (2006). What do we know about Firms' Research Collaboration with Universities? New Quantitative and Qualitative Evidence. Stockholm: The Royal Institute of Technology Centre of Excellence for Science and Innovation Studies.

Colyvas, J., Crow, M., Gelijns, A., Mazzoleni, R., Nelson, R.R., Rosenberg, N. (2002). How Do University Inventions Get Into Practice? Management Science, 48(1), 61-72.

Edukacja dla pracy. Raport o rozwoju społecznym. Polska 2007 (2007) (2017, 29 października). Pozyskano z http:// www.undp.org.pl/nhdr2007, 92

Employment and Social Developments in Europe. Quarterly Review (2017, 29 października). Pozyskano z ec.europa.eu/social/BlobServlet?docId=17031\&langId=en 
European Innovation Scoreboard 2017 (2017, 29 października). Pozyskano z https://www.rvo. nl/sites/default/files/2017/06/European_Innovation_Scoreboard_2017.pdf

Eurostat (2018, 2 czerwca). Pozyskano z: nama_10_a10_e; http://ec.europa.eu/eurostat/tgm/ table.do?tab=table\&init=1\&language=en\&pcode=t2020_41\&plugin $=1$

Eurostat regional yearbook 2017 (2017, 29 października). Pozyskano z http://ec.europa.eu/eurostat/documents/3217494/8222062/KS-HA-17-001-EN-N.pdf/eaebe7fa-0c80-45af-ab41-0f806c433763

Gajda, W. (2015). Innowacyjność polskiego przemysłu na tle przemysłu światowego. Prace Komisji Geografii Przemysłu Polskiego Towarzystwa Geograficznego, 29(1), 42-55.

Goldstain, H. (2009). What we know and what we don't know about the regional economic impacts of universities. W: A. Varga (red.). Universities, Knowledge Transfer and Regional Development. Cheltenham: Edward Elgar.

Howells, J.R.L. (2002). Tacit Knowledge, Innovation and Economic Geography. Urban Studies, 39(5-6), 871-884.

Jakóbik, W. (2000). Zmiany systemowe a struktura gospodarki w Polsce. Warszawa: Wydawnictwo Naukowe PWN, 18.

Kasperkiewicz, W. (2014). Uwarunkowania i perspektywy rozwoju innowacyjności gospodarek Unii Europejskiej w świetle Strategii Europa 2020. W: E. Dworak, T. Grabia, W. Kasperkiewicz, W. Kwiatkowska (red.). Gospodarka oparta na wiedzy, innowacyjność i rynek pracy. Łódź: Wydawnictwo Uniwersytetu Łódzkiego, 95-96.

Kuciński, K. (2010). Metodologia nauk ekonomicznych. Dylematy i wyzwania. Warszawa: Difin, 22.

Matusiak, M. (2005). Gospodarka oparta na wiedzy. W: K.B. Matusiak (red.). Innowacje i transfer technologii. Słownik pojęć. Warszawa: Polska Agencja Rozwoju Przedsiębiorczości, 57.

Niedzielski, P. (2005). Rodzaje innowacji. W: K.B. Matusiak (red.). Innowacje i transfer technologii. Słownik pojęć. Warszawa: Polska Agencja Rozwoju Przedsiębiorczości, 74-75.

Nowak, P. (2012). Poziom innowacyjności polskiej gospodarki na tle krajów UE. Prace Komisji Geografii Przemysłu Polskiego Towarzystwa Geograficznego, 19, 153-160.

Nowakowska, A. (2009). Regionalny kontekst procesów innowacji. W: A. Nowakowska (red.). Budowanie zdolności innowacyjnych regionów. Łódź: Wydawnictwo Uniwersytetu Łódzkiego, 20.

Pasinetti, L.L. (2006). Structural Economic Dynamics. A theory of the economic consequences of human learning. Cambridge: Cambridge University Press, 50.

Potencjał innowacyjny gospodarki: uwarunkowania, determinanty, perspektywy (2016). Warszawa: Narodowy Bank Polski, 22.

Salvadori, N., Commendatore, P., Tamberi, M. (red.) (2009). Geography, Structural Change and Economic Development: Theory and Empirics. Cheltenham: Edward Elgar, 10-11.

Thurow, L.C. (2006). Powiększanie bogactwa. Nowe reguły gry w gospodarce opartej na wiedzy. Gliwice: Wydawnictwo Helion, 73.

Węgrzyn, G. (2015). Innowacje w sektorze usług a zmiany strukturalne w zatrudnieniu. Wrocław: Wydawnictwo Uniwersytetu Ekonomicznego we Wrocławiu, 528.

Włodarczyk, J. (2011). Przemiany struktur gospodarczych w ujęciu systemowym. Katowice: Wydawnictwo Uniwersytetu Ekonomicznego w Katowicach, 81, 16.

Wysokińska, Z. (2011). Konkurencyjność w międzynarodowym i globalnym handlu technologiami. Warszawa-Łódź: Wydawnictwo Naukowe PWN.

Zaidi, M.A., Mukhopadhyay, S.K. (2006). Economic Development, Structural Change and Employment Potential, Employment, Income Distribution and Development. Stewart, Routledge, 64.

Zielińska-Głębocka, A. (2012). Współczesna gospodarka światowa. Przemiany, innowacje, kryzysy, rozwiq̨zania regionalne. Warszawa: Oficyna Wolters Kluwer, 52.

Zimmermann, K.F. (red.) (2002). Frontiers in Economics. Berlin: Springer-Verlag, 282.

Grażyna Węgrzyn, dr hab., prof. nadzw. Uniwersytetu Ekonomicznego we Wrocławiu, Wydział Ekonomii, Zarządzania i Turystyki w Jeleniej Górze, Katedra Ekonomii i Polityki Ekonomicznej. Zainteresowania badawcze: rynek pracy, innowacyjność, gospodarka oparta na wiedzy, makroekonomia, sektor usług. 
Grażyna Węgrzyn, an associate professor of economics, Wrocław University of Economics, Faculty of Economics, Management and Tourism in Jelenia Góra, Department of Economics and Economic Policy, Research interests: labour market, innovation, knowledge based economy, macroeconomics, services sector.

\section{Adres/address:}

Uniwersytet Ekonomiczny we Wrocławiu

Wydział Ekonomii, Zarządzania i Turystyki w Jeleniej Górze

Katedra Ekonomii i Polityki Ekonomicznej

ul. Nowowiejska 3, 58-500 Jelenia Góra, Polska

e-mail: grazyna.wegrzyn@ue.wroc.pl 